\title{
Naked-eye Detection of Amyloid Aggregates Using Gold Nanoparticles Modified with Amyloid Beta Antibody
}

\author{
Masafumi SAKono, ${ }^{*}, *+$ Tamotsu ZAKo, ${ }^{* *}$ and Mizuo MAEDA** \\ *PRESTO, Japan Science and Technology Agency, 3-5 Sanbancho, Chiyoda, Tokyo 102-0075, Japan \\ **Bioengineering Laboratory, RIKEN Institute, 2-1 Hirosawa, Wako, Saitama 351-0198, Japan
}

\begin{abstract}
We developed a rapid method for estimating the amyloid beta $(\mathrm{A} \beta)$-conformation state related with Alzheimer's disease. We prepared gold nanoparticle (AuNP)-A $\beta$ antibody conjugates treated with bovine serum albumin to stabilize their dispersibility in a buffer. The prepared AuNPs were precipitated in the presence of $\mathrm{A} \beta$ aggregates, such as oligomers and fibrils. $\mathrm{A} \beta$ monomers did not precipitate AuNPs. The formation of AuNP precipitates by $\mathrm{A} \beta$ aggregates could be confirmed by the naked eye within $1 \mathrm{~h}$.
\end{abstract}

(Received August 31, 2011; Accepted September 17, 2011; Published January 10, 2012)

\section{Introduction}

Amyloid beta $(\mathrm{A} \beta)$, a polypeptide composed of $39-43$ amino acids, is a causative agent of neurodegenerative disorder, Alzheimer's disease (AD). ${ }^{1,2} \mathrm{~A} \beta$ is known to aggregate spontaneously into $\beta$-sheet-rich fibrils. ${ }^{3}$ These water-insoluble fibrillar aggregates have neurotoxic properties. Recent studies have shown that soluble $\mathrm{A} \beta$ oligomers, which are an intermediate stage of $\mathrm{A} \beta$ fibrillation have more toxic properties than the fibrillar state., ${ }^{4,5}$ The formation of $\mathrm{A} \beta$ aggregates, such as oligomers and fibrils, is considered to be a trigger for $\mathrm{AD}$ neurodegeneration by affecting brain nerve cells. Conformation analysis of $\mathrm{A} \beta$ is therefore important for early recognition of AD.

There are several published reports related to $\mathrm{A} \beta$ detection. $\mathrm{A} \beta$ detection has been carried out mainly using enzyme-linked immunosorbent assays (ELISA) with $\mathrm{A} \beta$ antibody. ${ }^{6,7}$ Specific detection methods for $\mathrm{A} \beta$ oligomers using oligomer antibodies have also been reported recently, ${ }^{8,9}$ making it possible to determine the concentration of respective $\mathrm{A} \beta$ comformations. However, using ELISA is believed to be unsuitable for rapid $\mathrm{A} \beta$-conformation analysis, because these assays take several hours for signal detection. Alternatively, polyacrylamide gel electrophoresis (PAGE)/western blotting is available for $\mathrm{A} \beta$-conformation analysis. ${ }^{10}$ However, this method also takes a few hours for detection, and it is possible to cause dissociation of $\mathrm{A} \beta$ aggregates during electrophoresis. ${ }^{11}$ These methods used to detect $\mathrm{A} \beta$ in ordinal amyloid studies are considered to be suitable for a quantitative analysis such as size and amounts of $\mathrm{A} \beta$ aggegates, but not appropriate for a rapid estimation of the $\mathrm{A} \beta$-conformation. Recently, several methods concerning the rapid detection of $\mathrm{A} \beta$ were reported. Using two kinds of $\mathrm{A} \beta$ antibody modified with different fluorescent chemicals, Santos et al. reported the detection of $\mathrm{A} \beta$ aggregates based on fluorescence resonance energy transfer (FRET), ${ }^{12}$ which enables

† To whom correspondence should be addressed.

E-mail: msakono@riken.jp to detect the $\mathrm{A} \beta$ oligomer and fibril within $90 \mathrm{~min}$. However, this method requires the use of a fluorescence spectrometer equipped a FRET signal detector, and is thought not to be an easy-to-use approach. Another oligomer detection method using a peptide that recognizes the $\mathrm{A} \beta$ oligomer specifically was reported. ${ }^{13}$ This method allowed $\mathrm{A} \beta$ oligomer detection within $1 \mathrm{~h}$, while the detection of fibril was not possible. Therefore, the development of a simple and rapid detection method of $\mathrm{A} \beta$ aggregates, including both oligomers and fibrils, is required.

In this study, we aimed to develop a novel, rapid method for determining the $\mathrm{A} \beta$-conformation. A detection system that estimates existence of $\mathrm{A} \beta$ aggregates, but not an ordinal quantitative $\mathrm{A} \beta$ detection method, was developed. Our method enabled determining whether the $\mathrm{A} \beta$-conformation was a monomer or aggregate state within $1 \mathrm{~h}$ using $\mathrm{A} \beta$ antibodies and gold nanoparticles (AuNPs). We believe that this method may also be used to screen for various amyloid peptides other than $\mathrm{A} \beta$.

\section{Experimental}

\section{Reagents and chemicals}

$\mathrm{A} \beta(1-42)$ was purchased from Peptide Institute (Osaka, Japan), phenol red-free Ham's F12 medium from Biosource (Rockville, MD), mouse monoclonal $\mathrm{A} \beta$ antibody (6E10) from Covance (Berkeley, CA), and BCA protein assay reagent from Thermo Scientific (Roskilde, Denmark). AuNPs, $200 \mathrm{~nm}$ in diameter, were purchased from British Biocell International (UK), and a PBS solution (137 mM NaCl, $8.1 \mathrm{mM} \mathrm{Na}_{2} \mathrm{HPO}_{4}$, $2.68 \mathrm{mM} \mathrm{KCl}, 1.47 \mathrm{mM} \mathrm{KH} \mathrm{PO}_{4}$ ) from Nippon Gene (Japan). Bovine serum albumin (BSA) was obtained from Sigma Chemical Company (St Louis, MO), and a protein molecular weight marker from Bio-Rad (Hercules, CA). All other chemicals were purchased from Wako Pure Chemical Industries (Osaka, Japan).

Preparation of $A \beta$ samples

Seed-free $\mathrm{A} \beta$ monomers were prepared according to a previous 
report. $^{14}$ Briefly, synthetic $\mathrm{A} \beta 42$ was dissolved in a $0.1 \%$ ammonia water solution at $500 \mu \mathrm{M}$, and then centrifuged at $100000 \mathrm{rpm}$ for $3 \mathrm{~h}$ at $4^{\circ} \mathrm{C}$ using the Optima TL Ultracentrifuge (Beckman Instruments, Fullerton, CA) to remove undissolved peptide aggregates. The supernatant was collected and stored in aliquots at $-80^{\circ} \mathrm{C}$. Before use, the aliquots were thawed on ice and diluted with PBS. The $\mathrm{A} \beta$ oligomer was prepared according to Costantini et al. ${ }^{15}$ Briefly, the $\mathrm{A} \beta 42$ monomer stock was diluted to $100 \mu \mathrm{M}$ in an ice-cooled phenol red-free Ham's F12 medium, and then incubated at $37^{\circ} \mathrm{C}$ for $24 \mathrm{~h}$. The oligomer solution was centrifuged at $15000 \mathrm{rpm}$ for $15 \mathrm{~min}$, followed by collection of the supernatant containing soluble $\mathrm{A} \beta$ oligomer. $\mathrm{A} \beta$ fibrils were prepared by incubating the $\mathrm{A} \beta 42$ monomer stock, diluted to $100 \mu \mathrm{M}$ in PBS, for $24 \mathrm{~h}$ at $50^{\circ} \mathrm{C}$. The solution was centrifuged at $15000 \mathrm{rpm}$ for $15 \mathrm{~min}$ to remove excess monomers and oligomers and the precipitates were collected as $\mathrm{A} \beta$ fibrils. The concentration of the $\mathrm{A} \beta$ samples was measured using the BCA protein assay kit according to the manufacturer's instructions.

\section{Immobilization of $A \beta$ antibodies on $A u N P$}

A $100-\mu l$ aliquot of AuNPs obtained from BBI was added to a microtube, and then centrifuged at $10000 \mathrm{rpm}$ for $10 \mathrm{~min}$. The supernatant was removed, and AuNP precipitates remaining in the tubes were suspended to $100 \mu \mathrm{l}$ in 10-times diluted PBS including the $50 \mathrm{nM} \mathrm{A} \beta$ antibody (6E10), followed by incubation for $1 \mathrm{~h}$ at room temperature. After incubation, $100 \mathrm{ml}$ of 10 -times diluted PBS containing $5 \mathrm{wt} \%$ BSA was added to the microtube, followed by incubation for $30 \mathrm{~min}$. The microtube was then centrifuged at $8000 \mathrm{rpm}$ for $15 \mathrm{~min}$, and the supernatant removed. AuNPs precipitates were re-suspended in $1 \times$ PBS and used for further study.

\section{Confirmation of $A \beta$ antibodies immobilization on AuNP}

A $10-\mu l$ aliquot of AuNPs modified with $\mathrm{A} \beta$ antibody prepared in above step was transferred to a new microtube. The AuNPs were centrifuged, and the supernatant was removed. The AuNPs were re-suspended in 10- $\mu$ l of SDS loading buffer containing $10 \% \beta$-mercaptoethanol and then denatured at $98^{\circ} \mathrm{C}$ for $3 \mathrm{~min}$. Following separation for $60 \mathrm{~min}$ by SDS-PAGE on $10-20 \%$ Tris-glycine gels at a constant current of $20 \mathrm{~mA}$, the total proteins on the gels were detected with Coomassie Brilliant blue R-250.

DLS experiments were performed using Zetasizer Nano instrument (Malvern Instruments, Worcestershire, UK). A 50- $\mu 1$ aliquot of solution containing AuNPs was transferred to a $1 \times 1 \mathrm{~cm}$ fluorescence cuvette (Hellma, Müllheim, Germany) and measured using a 4-mW He-Ne laser (633 nm wavelength) with a fixed detector angle of $173^{\circ}$, under temperature-controlled conditions at $25^{\circ} \mathrm{C}$ with a tolerance of $\pm 0.02^{\circ} \mathrm{C}$.

\section{$A \beta$ detection using AuNPs modified with $A \beta$ antibodies}

The microtubes containing AuNPs modified with the $\mathrm{A} \beta$ antibody were centrifuged at $8000 \mathrm{rpm}$ for $15 \mathrm{~min}$, and the supernatant was removed. An appropriate concentration of the $\mathrm{A} \beta$ samples was added to the microtubes, and the precipitates of AuNPs were suspended by pipetting. After incubation for $1 \mathrm{~h}$ at $37^{\circ} \mathrm{C}$, the samples were observed by naked eye and the UV spectrum measured by UV-Vis spectroscopy. The absorbance of AuNPs over the range 400 to $700 \mathrm{~nm}$ was measured using Cary-50 UV-Vis spectrophotometer (Varian).

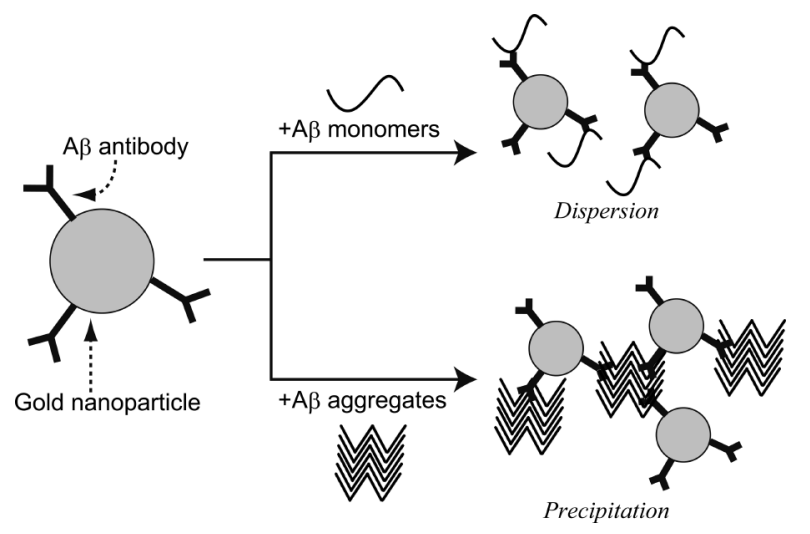

Fig. 1 Schematic illustration of the $\mathrm{A} \beta$-conformation assay using AuNP modified with $\mathrm{A} \beta$ antibody.

\section{Results and Discussion}

Figure 1 shows a schematic illustration of the $\mathrm{A} \beta$-conformation assay using AuNP modified with $\mathrm{A} \beta$ antibodies. $\mathrm{A} \beta$ antibodies immobilized on AuNP were reacted with $\mathrm{A} \beta$ in a buffer by an antigen-antibody reaction. When $\mathrm{A} \beta$ antibodies interact with the $\mathrm{A} \beta$ monomer, AuNP may remain dispersed in the buffer solution. On the other hand, AuNPs are supposed to form huge complexes in the presence of $\mathrm{A} \beta$ aggregates, since these aggregates possess many epitope sites for the $\mathrm{A} \beta$ antibody. By observing the complex formation of AuNPs, the confirmation of $\mathrm{A} \beta$ in a buffer solution can be estimated.

Firstly, the preparation of AuNP modified with $\mathrm{A} \beta$ antibodies was investigated. When AuNPs untreated with BSA were suspended in a $1 \times$ PBS solution in a microtube, they adsorbed to the polypropylene microtube wall (Fig. 2a). This nonspecific adsorption between polypropylene and AuNPs is believed to be caused by an increase in the surface hydrophobicity of AuNPs by salt contained in the PBS. ${ }^{16,17}$ The absorption spectra of AuNPs remained decreased compared to AuNPs in water even when the $\mathrm{A} \beta$ antibody concentration was increased (Fig. 2b). On the other hand, when AuNPs treated with BSA were suspended in a $1 \times$ PBS solution, their absorbance values were much higher than those of untreated AuNP (Fig. 2c). Moreover, nonspecific adsorption of AuNPs to the microtube wall was not observed (Fig. 2a). This result indicates that BSA is an effective additive for stabilization of AuNPs dispersed in a buffer solution.

We next confirmed immobilization of the $\mathrm{A} \beta$ antibody on AuNPs using SDS-PAGE. Figure 3 shows bands of protein immobilized on the surface of AuNP. As shown in the figure, the $\mathrm{A} \beta$ antibody was observed in the lane of AuNPs treated with BSA, supporting successful immobilization. On the other hand, no protein bands were indicated in the lane of AuNPs untreated with BSA. This might be because only a small amount of AuNPs modified with the $\mathrm{A} \beta$ antibody was present in the $1 \times$ PBS solution due to adsorption onto the microtube. To further confirm antibody immobilization, the diameter of these AuNPs modified with the $\mathrm{A} \beta$ antibody was measured by DLS analysis (data not shown). The results show that the diameter of AuNPs treated with BSA and untreated AuNPs were 37.0 and $23.1 \mathrm{~nm}$, respectively. Since the length of the IgG type antibody is approximately $8 \mathrm{~nm},{ }^{18}$ this result also suggests that multiple $\mathrm{A} \beta$ antibodies are immobilized on the AuNP surface. These results indicate that $\mathrm{A} \beta$ antibodies are adsorbed onto the AuNP surface, resulting in the formation of complexes of AuNPs modified with the $\mathrm{A} \beta$ antibody. 
(a)

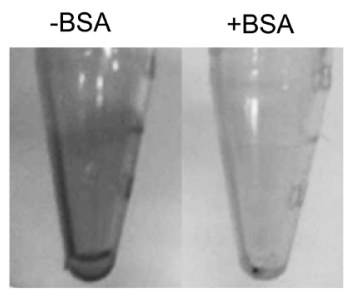

(b)

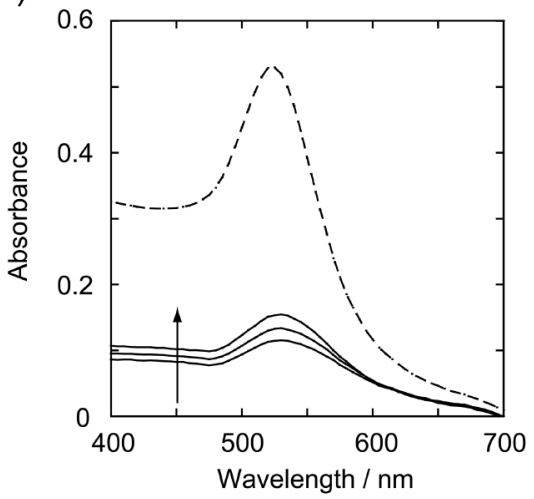

(c)

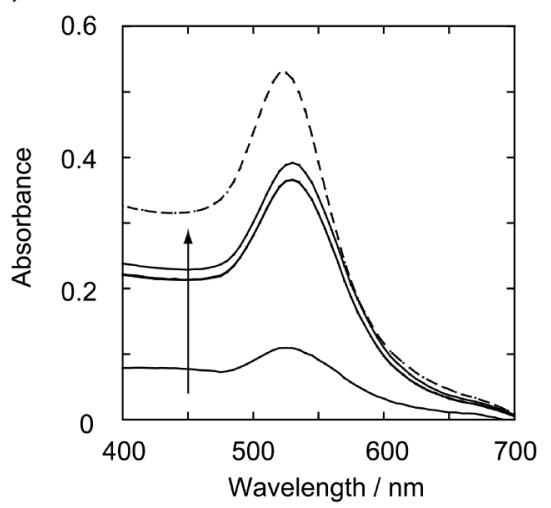

Fig. 2 Improvement of AuNP dispersion stability by the addition of BSA. (a) Photograph of AuNPs adsorbed on the surface of a microtube. (b) Absorption spectra of AuNPs untreated with BSA. The direction of the arrow shows 40,50, and $60 \mathrm{nM}$ antibody concentrations, while the dotted line indicates the AuNP spectrum in MQ. (c) Absorption spectra of AuNPs treated with BSA. The direction of the arrow shows $0,1,5$, and $10 \mathrm{wt} \%$ of BSA concentration, while the dotted line indicates the AuNP spectrum in MQ.

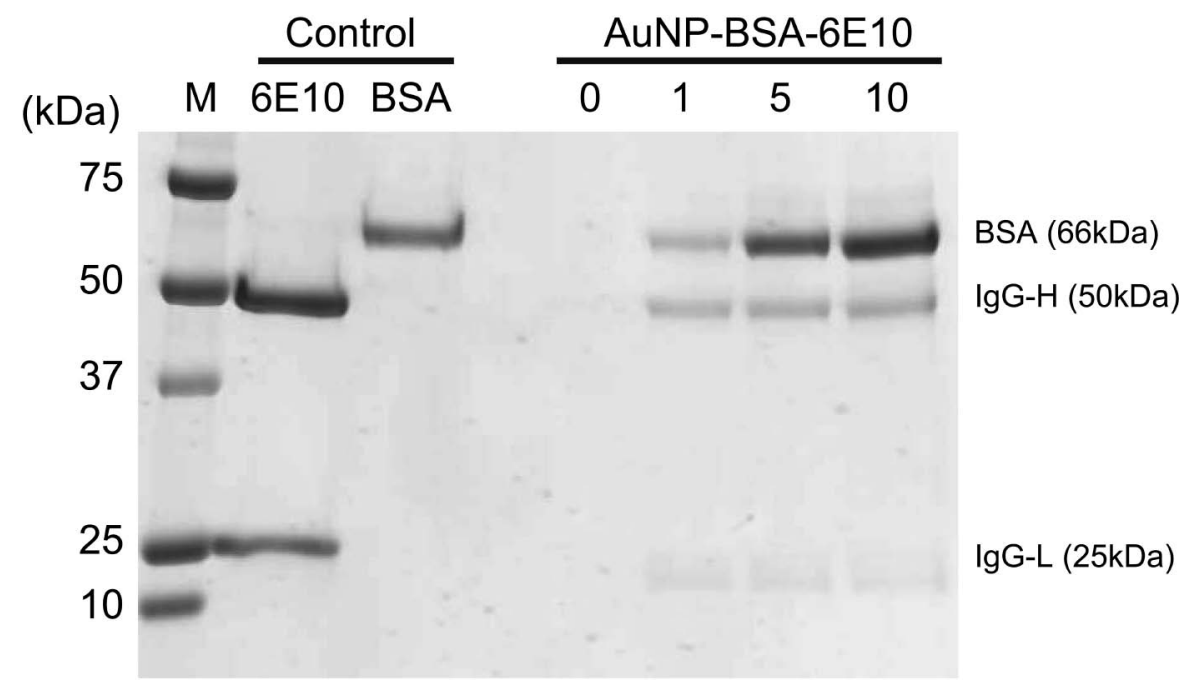

Fig. 3 Confirmation of BSA or A $\beta$ antibody immobilization on AuNPs by SDS-PAGE. The left lane (M) shows the commercially available protein size marker. The control lanes show the bands of $\mathrm{A} \beta$ antibody (6E10) and BSA. Two bands, IgG heavy chain (IgG-H) and IgG light chain (IgG-L), were shown in the lane of $6 \mathrm{E} 10$ due to reduction of IgG type antibody. The AuNP-BSA-6E10 lanes show the AuNP sample modified with $\mathrm{A} \beta$ antibody after a BSA treatment, with the numbers from 0 to 10 representing the BSA concentration from 0 to $10 \mathrm{wt} \%$, respectively.

The interaction of AuNPs modified with $\mathrm{A} \beta$ antibody after treatment with $5 \%$ BSA and $\mathrm{A} \beta$ in various conformation states was then examined (Fig. 4). When $5 \mu \mathrm{M}$ of the $\mathrm{A} \beta$ monomer was added to a PBS solution containing AuNPs and incubated at $37^{\circ} \mathrm{C}$ for $1 \mathrm{~h}$, a significant change was not observed visually. The absorption spectrum also showed that the absorbance remained unchanged. In contrast, in the presence of the $\mathrm{A} \beta$ oligomer, red-colored precipitates were confirmed by the naked eye, and the absorption spectra showed a decrease in absorbance. Similarly, the addition of $5 \mu \mathrm{M} \mathrm{A} \beta$ fibrils induced the production of red-colored precipitates, although precipitation did not occur with $10 \mathrm{nM} \mathrm{A} \beta$ fibrils. This might be because the interaction between the $\mathrm{A} \beta$ antibodies and $\mathrm{A} \beta$ fibrils is weak since the fibrils have different hydrophobic properties than the oligomers. Therefore, the addition of $\mathrm{A} \beta$ fibrils at low concentrations may be insufficient to form precipitates. Our results indicates that A $\beta$ aggregates, both oligomer and fibril, are able to be detected using AuNPs modified with the $\mathrm{A} \beta$ antibody within $1 \mathrm{~h}$. Especially, this $\mathrm{A} \beta$-conformation analysis is useful for simple and rapid detection of $\mathrm{A} \beta$ aggregates, because this method enables to determine the $\mathrm{A} \beta$-conformation with naked-eye.

Interestingly, precipitates formed by the addition of oligomers or fibrils maintained a red color that originated from the surface plasmon band of AuNPs. The aggregation of AuNPs is generally known to cause a characteristic transition in solution color from red to purple-violet. ${ }^{17}$ Therefore, we speculate that the production of huge complexes between $\mathrm{A} \beta$ aggregates and AuNPs, rather than aggregate formation of AuNPs, results in precipitation. 


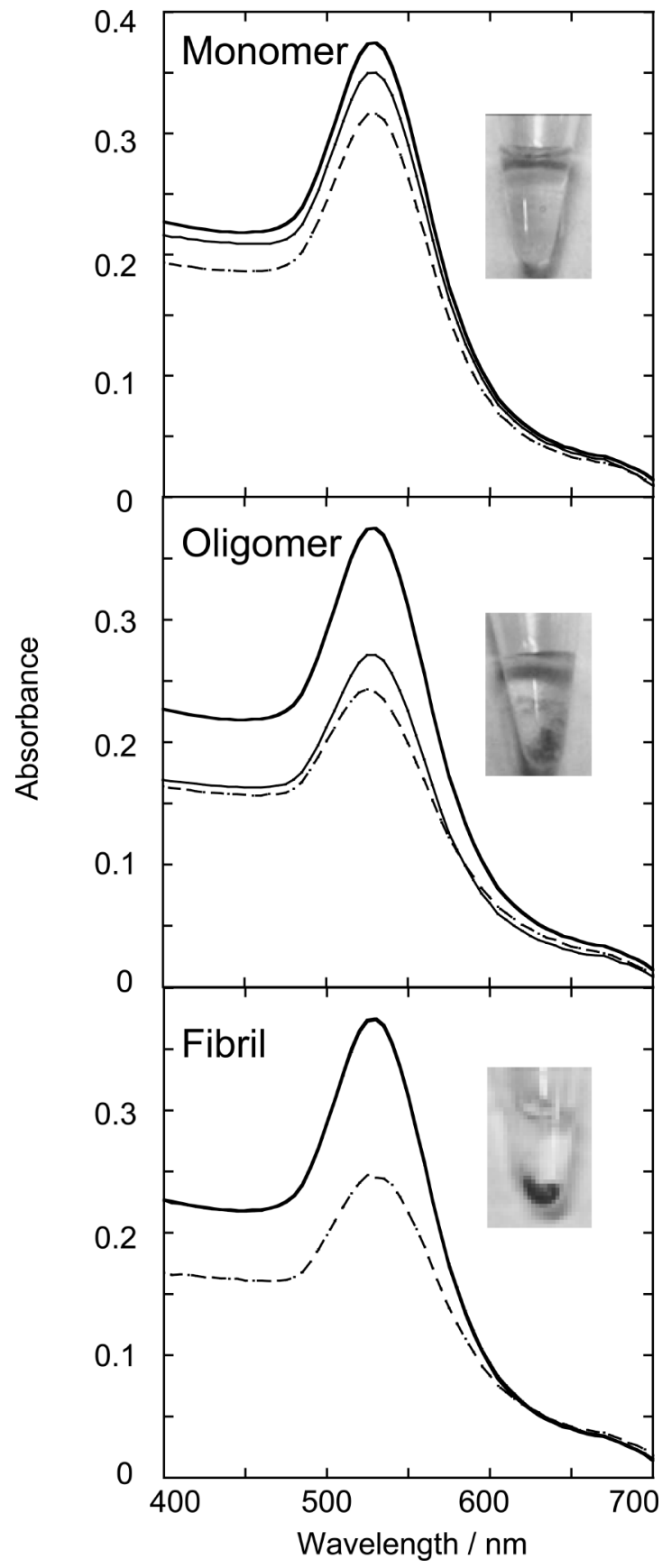

Fig. 4 Absorption spectra of AuNPs and photograph of AuNP solutions in the presence of $\mathrm{A} \beta$ samples in various conformation states. The bold line indicates the AuNP spectrum without $\mathrm{A} \beta$ samples. The dotted and solid lines show spectra with $5 \mu \mathrm{M}, 10 \mathrm{nM}$ of $\mathrm{A} \beta$ samples, respectively.

\section{Conclusions}

AuNPs modified with $\mathrm{A} \beta$ antibody were prepared for a $\mathrm{A} \beta$-conformation assay. The treatment of AuNPs with BSA caused a reduction of the nonspecific adsorption to the microtube due to an increase of the AuNPs dispersion stability. Red-colored precipitates were observed by the naked eye in the presence of $\mathrm{A} \beta$ aggregates such as oligomers and fibrils, while no change was observed in the presence of $\mathrm{A} \beta$ monomers. Our results suggest that AuNPs modified with the $\mathrm{A} \beta$ antibody are effective for the simple and rapid detection of $\mathrm{A} \beta$ aggregates that are causative agents of $\mathrm{AD}$.

\section{Acknowledgements}

The authors are grateful for financial support by RIKEN (Nano-scale Science and Technology Research). This work was also supported by the Japan Science Technology Agency (PRESTO Program; to M. S.).

\section{References}

1. M. P. Murphy and H. LeVine, 3rd, J. Alzheimers Dis., 2010, 19, 311.

2. D. J. Selkoe, Physiol. Rev., 2001, 81, 741.

3. L. C. Serpell, Biochim. Biophys. Acta, 2000, 1502, 16.

4. W. L. Klein, G. A. Krafft, and C. E. Finch, Trends Neurosci., 2001, 24, 219.

5. M. Sakono and T. Zako, FEBS J., 2010, 277, 1348.

6. S. A. Gravina, L. Ho, C. B. Eckman, K. E. Long, L. Otvos, Jr., L. H. Younkin, N. Suzuki, and S. G. Younkin, J. Biol. Chem., 1995, 270, 7013.

7. G. M. Hayes, D. R. Howlett, and G. E. Griffin, Neuroscience, 2002, 113, 641.

8. H. LeVine, 3rd, Anal. Biochem., 2004, 335, 81.

9. Z. van Helmond, K. Heesom, and S. Love, J. Neurosci. Methods, 2009, 176, 206.

10. M. P. Lambert, A. K. Barlow, B. A. Chromy, C. Edwards, R. Freed, M. Liosatos, T. E. Morgan, I. Rozovsky, B Trommer, K. L. Viola, P. Wals, C. Zhang, C. E. Finch, G. A. Krafft, and W. L. Klein, Proc. Natl. Acad. Sci. U. S. A., 1998, 95, 6448.

11. M. Sakono, T. Zako, H. Ueda, M. Yohda, and M. Maeda, FEBS J., 2008, 275, 5982.

12. A. N. Santos, S. Torkler, D. Nowak, C. Schlittig, M. Goerdes, T. Lauber, L. Trischmann, M. Schaupp, M. Penz, F. W. Tiller, and G. Bohm, J. Alzheimers Dis., 2007, 11, 117.

13. Y. Hu, B. Su, C. S. Kim, M. Hernandez, A. Rostagno, J. Ghiso, and J. R. Kim, ChemBioChem, 2010, 11, 2409.

14. K. Hasegawa, I. Yamaguchi, S. Omata, F. Gejyo, and H. Naiki, Biochemistry, 1999, 38, 15514.

15. C. Costantini, V. Della-Bianca, E. Formaggio, C. Chiamulera, A. Montresor, and F. Rossi, Exp. Cell Res. 2005, 311, 126.

16. S. G. Oh, S. H. Park, J. Y. Mun, S. S. Han, Colloids Surf., $B, \mathbf{2 0 0 6}, 48,112$.

17. M. Sakono, T. Zako, S. Drakulic, J. M. Valpuesta, M. Yohda, and M. Maeda, Chem. Phys. Lett., 2010, 501, 108.

18. Y. H. Tan, M. Liu, B. Nolting, J. G. Go, J. Gervay-Hague, and G. Y. Liu, ACS Nano, 2008, 2, 2374. 